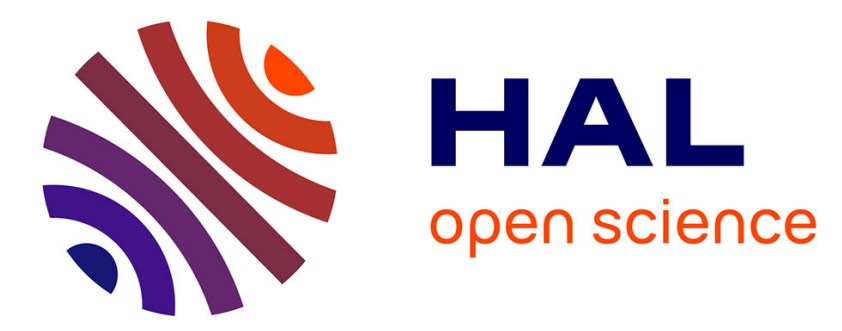

\title{
Relationship Networks: Social Innovation and Earnings for Companies
}

Marcelo T. Okano, Oduvaldo Vendrametto, Marcelo Eloy Fernandes, Osmildo Santos

\section{- To cite this version:}

Marcelo T. Okano, Oduvaldo Vendrametto, Marcelo Eloy Fernandes, Osmildo Santos. Relationship Networks: Social Innovation and Earnings for Companies. IFIP International Conference on Advances in Production Management Systems (APMS), Sep 2016, Iguassu Falls, Brazil. pp.86-95, 10.1007/9783-319-51133-7_11. hal-01615706

\section{HAL Id: hal-01615706 https://hal.inria.fr/hal-01615706}

Submitted on 12 Oct 2017

HAL is a multi-disciplinary open access archive for the deposit and dissemination of scientific research documents, whether they are published or not. The documents may come from teaching and research institutions in France or abroad, or from public or private research centers.
L'archive ouverte pluridisciplinaire HAL, est destinée au dépôt et à la diffusion de documents scientifiques de niveau recherche, publiés ou non, émanant des établissements d'enseignement et de recherche français ou étrangers, des laboratoires publics ou privés.

\section{(c)(1)}

Distributed under a Creative Commons Attribution| 4.0 International License 


\title{
Relationship Networks: Social Innovation and Earnings for Companies
}

\author{
Marcelo T. Okano ${ }^{1},{ }^{*}$, Oduvaldo Vendrametto ${ }^{2}$, Marcelo Eloy Fernandes ${ }^{3}$, Osmildo S. \\ Dos Santos 4 \\ ${ }^{1}$ Getulio Vargas Foundation, SP, Brazil \\ ${ }^{2}$ Paulista University, SP, Brazil \\ ${ }^{3}$ Fatec Barueri/Uninove, SP, Brazil \\ ${ }^{4}$ Universidade Potiguar, SP, Brazil \\ marcelo.okano@fatec.sp.gov.br
}

\begin{abstract}
This study proposes an investigation to prove that when companies organize in networks and use social innovation in a productive system gets economic and social gain. The object of study is a case study of Milk Producers Association of Fartura, São Paulo. The object of study is a case study of Milk Producers Association of Fartura, São Paulo. This case study can be interpreted as a social innovation, as the association of producers brought social and economic benefits for a community; there has been new products and processes in order to innovate the marketing and production of lasting and sustainable milk.
\end{abstract}

Keywords: Social innovation $\cdot$ Network $\cdot$ Milk

\section{Introduction}

Innovation and its cycle can historically be divided into three stages: invention, present since the beginning of mankind; imitation or diffusion, common in markets whose economy was underpinned by the production and outsourcing of consumer products and innovation, strategy for economic sustainability of organizations in the twenty-first century, emerging after economic globalization and alternative to keep up with demand speed for new products, feature contemporary dynamics [1].

A new type of innovation begins to emerge; concerns about social issues begin to appear and to be important for organizations, called social innovation. According Juliani et al. [2], the mobilization around the theme stems from the lack of state capacity meet the needs of the population and the policies that direct public investment to increase competitiveness at the expense of social development.

Often these social changes begin mobilizing stakeholders to form a interorganizational network level, the companies operate in a network when there is cooperation and commitment in the relationship between them, providing not only economic gains, but also social.

adfa, p. 1, 2011.

(C) Springer-Verlag Berlin Heidelberg 2011 
This study proposes an investigation to prove that when companies organize in networks and use social innovation in a productive system gets economic and social gain. The object of study is a case study of Milk Producers Association of Fartura, São Paulo.

\section{Conceptual Reference}

\subsection{Interorganizational Networks}

Puffal and Puffal [3], consider based on research conducted on the evolution of interorganizational networks studies field that the past 30 years the interest on interorganizational networks has grown significantly, and produced several studies and publications on the subject and the theme networks interorganizational is a fragmented field, multidisciplinary and his studies being conducted from various theories, from various points of view it is necessary to periodically analyze this field of study and to identify the most discussed topics and the light which theories it is being analyzed.

Companies operating in network when there is cooperation and commitment in the relationship between them. A growing use of information systems to interconnect companies - the so-called inter-organizational systems [4].

As a result, companies adopt new forms of work management, innovate in the concern to adjust to the global requirements and create collaborative strategies as a way to acquire skills that do not yet have, and corroborate DYER \& SINGH [5].

Interorganizational networks are important in economic life, because facilitate the complex transactional and cooperative interdependence between organizations. Its importance is recognized from the point of theoretical saw, because it can be, and indeed are studied from different theoretical approaches. Thus, studies on networks provide a valuable basis of common interests and potential dialogue between the various branches of social science [7].

According to Baum and Ingram [8], inter-organizational networks can be divided into two classes analysis: horizontal and vertical networks. Figure 1 reflects the main divisions of studies on inter-organizational networks [6].

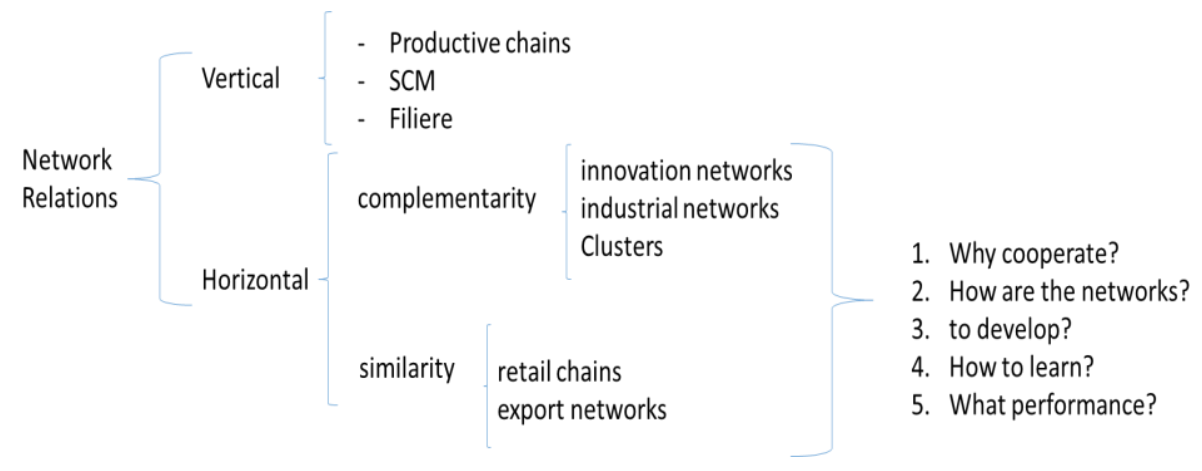

Fig. 1. Divisions of inter-organizational networks - Source: Pereira [6] 
Among the types of networks, there are the so-called social networks, which have characteristics similar to the others, especially the line towards a common goal among the actors and decentralization in decision-making with the participation of individuals and organizations. Table 1 describes the main characteristics of the types of networks.

\subsection{Social Business}

Organizations with unique view on offer and demand fluctuations have a short-time management, are closed to new markets generated by new demands. Consequently, closed to the innovative process and its vital contribution to growth [1].

According to Yunus et al. [10], in the capitalist system, two extreme types of corporate bodies can be distinguished. On the one hand, companies can be seen as profitmaximizing businesses, whose purpose is to create shareholder value. On the other, non-profit organizations exist to fulfil social objectives. In organizational structure, this new form of business is the same as profit-maximizing businesses: it is not a charity, but a business in every sense.

Table 1. Characteristics of the types of networks

\begin{tabular}{|c|c|c|c|c|}
\hline Characteristics & Agglomerate & Cluster & $\begin{array}{l}\text { Local Productive } \\
\text { Arrangement }\end{array}$ & Social networks \\
\hline Types of actors involved & $\begin{array}{c}\text { Private and public } \\
\text { organizations. }\end{array}$ & $\begin{array}{l}\text { Private and public } \\
\text { organizations }\end{array}$ & $\begin{array}{c}\text { Private, public, } \\
\text { educational } \\
\text { institutions, non- } \\
\text { governmental } \\
\text { organizations, } \\
\text { associations, unions } \\
\text { and the community in } \\
\text { general. }\end{array}$ & $\begin{array}{c}\text { Private, public, } \\
\text { educational } \\
\text { institutions, non- } \\
\text { governmental } \\
\text { organizations, } \\
\text { associations, unions } \\
\text { and the community in } \\
\text { general }\end{array}$ \\
\hline Form of actors & Organizations & Organizations & Organizations & $\begin{array}{l}\text { Organizations and } \\
\text { individuals. }\end{array}$ \\
\hline Typology & Market & $\begin{array}{l}\text { Market and } \\
\text { communications }\end{array}$ & $\begin{array}{c}\text { Market, } \\
\text { communications and } \\
\text { support }\end{array}$ & Support \\
\hline Models & $\begin{array}{l}\text { Vertical and } \\
\text { horizontal }\end{array}$ & Vertical and horizontal & Vertical and horizontal & Horizontal \\
\hline $\begin{array}{l}\text { Organizations in a given } \\
\text { geographical area }\end{array}$ & concentrated & concentrated & concentrated & concentrated \\
\hline Types of organizations & Various sectors & A sector or activity & A sector or activity & $\begin{array}{c}\text { One or more sectors or } \\
\text { activities }\end{array}$ \\
\hline Strategy level & organizational & Organizational & $\begin{array}{l}\text { Among all the local } \\
\text { agents }\end{array}$ & $\begin{array}{c}\text { Among all the local } \\
\text { agents }\end{array}$ \\
\hline Actions & competitive & $\begin{array}{l}\text { Competitive- } \\
\text { cooperative }\end{array}$ & $\begin{array}{l}\text { Competitive- } \\
\text { cooperative }\end{array}$ & Cooperatives \\
\hline Interaction Form & $\begin{array}{l}\text { Formal and } \\
\text { informal }\end{array}$ & Formal & Formal & Informal \\
\hline $\begin{array}{l}\text { Essential factors of } \\
\text { strengthening }\end{array}$ & $\begin{array}{l}\text { Geographical } \\
\text { proximity, } \\
\text { similarity of } \\
\text { market and } \\
\text { regional } \\
\text { competences. }\end{array}$ & $\begin{array}{c}\text { Geographical } \\
\text { proximity, similarity of } \\
\text { market, regional } \\
\text { expertise and strong } \\
\text { competition. }\end{array}$ & $\begin{array}{l}\text { Close geographic, } \\
\text { similar market, } \\
\text { regional expertise, } \\
\text { strong competition } \\
\text { and social } \\
\text { cooperation. }\end{array}$ & $\begin{array}{l}\text { Trust, reputation and } \\
\text { cooperation }\end{array}$ \\
\hline Goal setting & Does not exist & $\begin{array}{c}\text { Common goals } \\
\text { between partners }\end{array}$ & $\begin{array}{l}\text { Common objectives } \\
\text { with all local actors }\end{array}$ & $\begin{array}{l}\text { Common objectives } \\
\text { with all local actors }\end{array}$ \\
\hline Types of Goals & Economics & Economics & $\begin{array}{c}\text { Economics and } \\
\text { Socials }\end{array}$ & Economics and Socials \\
\hline
\end{tabular}


A social business is designed and operated just like a 'regular' business enterprise, with products, services, customers, markets, expenses and revenues. It is a no-loss, nodividend, self-sustaining company that sells goods or services and repays investments to its owners, but whose primary purpose is to serve society and improve the lot of the poor. Here it differs from NGOs, most of which are not designed to recover their total costs from their operations, and are therefore obliged to devote part of their time and energy to raising money. As it seeks self-sustainability, a social business only relies on its investors at the beginning of a development project [10].

\section{Business Models.}

a) Conventional business model.

Yunus et al. [10] suggest that a business model has three components, as shown in Figure 2:
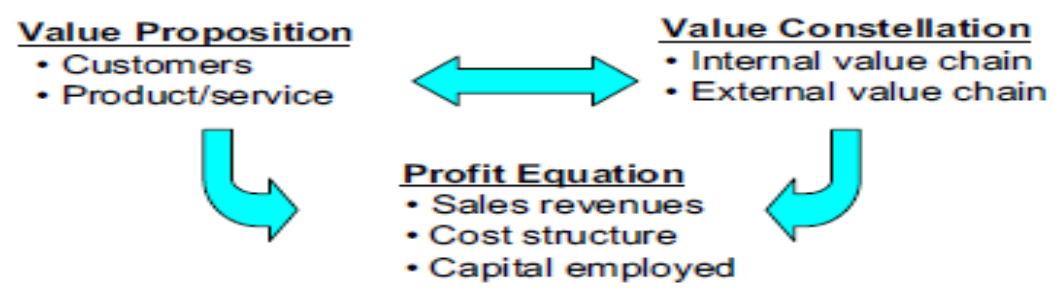

Fig. 2. The three components of a conventional business model Source: Yunus et al. [10].

- A value proposition, that is, the answer to the question: 'Who are our customers and what do we offer to them that they value?'

- A value constellation, that is, the answer to the question: 'How do we deliver this offer to our customers?' This involves not only the company's own value chain but also its value network with its suppliers and partners.

These two components need to fit together like pieces of a puzzle in order to generate:

- A positive profit equation, which is the financial translation of the other two, and includes how value is captured from the revenues generated through the value proposition, and how costs are structured and capital employed in the value constellation.

b) Social Business Model.

To adapt the model to the social business, Yunus et al. [10] propose the following changes: The first change is the specification of targeted stakeholders, and the provision that the value proposition and constellation are not focused solely on the customer, but are expanded to encompass all stakeholders. The second is the definition of desired social profits through a comprehensive eco-system view, resulting in a social profit equation. The third is that the economic profit equation targets only full recovery of 
cost and of capital, and not financial profit maximization. Figure 3 illustrates these changes.

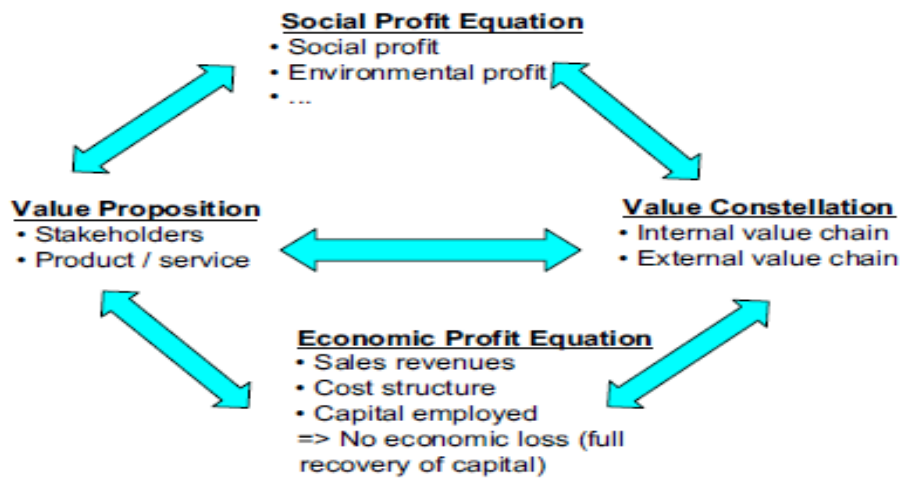

Fig. 3. The four components of a social business mode. Source: Yunus et al. [10].

\subsection{Social innovation}

The social innovation process produces the effect of reconstructing the social relations systems, as well as the structure of rules and resources that reproduce such systems. Therefore, according to the author, just it comes to social innovation "when the changes alter the processes and social relations, changing the pre-existing power structures" [11].

Already, Cloutier [12] considers social innovation as a new response, defined in the action and with lasting effect, to a social situation deemed unsatisfactory, that seeks the well-being of individuals and/or communities. To Bignetti [13], is the result of knowledge applied to social needs through the participation and cooperation of all stakeholders, creating new and lasting solutions to social groups, communities or society.

To Castor et al. [14] include "search, discovery, experimentation, development, imitation and adoption of" alternative social arrangements "to produce something". Murray et al. [15] defines how new ideas (products, services and models) that simultaneously satisfy social needs and create new social relationships or collaborations.

The concept of social innovation in order to generate social change refers to the concern with the idea of improving living conditions, create opportunities and provide a more fraternal society. Therefore, social innovation arises from a desire or a need not being met by the State or by the market and are mainly in developing countries, more work space, the conditions of degradation of human life [16]. 


\section{Method}

To achieve the objective of this study an exploratory survey was conducted, qualitative, along with the milk producers of Fartura region, state of São Paulo. Gil [17], the exploratory research aims to provide greater awareness of the problem, in order to make it more explicit.

The qualitative approach presents a reality that cannot be quantified or measured and involves subjective items of reality research. It can work with data without specific statistical analysis, seeking the understanding of reality [18]. The research used the following methodologies:

1. Bibliographic Survey: Is the survey and review of all literature used for the theoretical foundation of the research.

2. Case Study: To accomplish the gathering of information, it was necessary to resort to the case study to evaluate the scenarios analyzed. The case study, according to Gil [17], need not be a hard road, closed.

\section{$4 \quad$ Results}

After a literature review, which served as a theoretical basis for the development of the survey instrument, selected the main features to prove the case of Fartura producers' association can be characterized as a social innovation.

\subsection{Scenario before the producers' association}

The several visits and interviews in various dairy farms of Fartura region shown that the Interorganizational relationships were small and largely were limited to the sale of milk to cooperatives or dairy. These relationships were related just trade relations between the owner and the purchaser of milk. The buyer of milk just paid a fixed amount for a litter of milk, without any differentiation. There was an association of producers, cooperative or cluster, making it difficult to characterize an organizational inter network.

\subsection{Formation of the Producers Association}

A dairy company (Frutap) would launch a new product, a type of fermented milk, but need milk with a better quality. Quality milk production differs slightly from traditional definitions, therefore, are considered items such as protein, fat and total solids. To achieve improvement in milk, producers would have to improve production by investing in genetic control, artificial insemination, endemic controls, improved feeding and pastures adoption of strict inspection, handling, cleaning and disinfection.

In return the dairy company would pay more for better quality milk. The properties that adhered to change had a year to adapt the requirements. In this period, producers began meeting to create the association. 


\subsection{Scenario after the formation of the Producers Association}

In the city of Fartura, there is a group of 34 dairy farmers who have organized themselves into an association and provide for a dairy company with different prices according to the quality of the milk produced, as well as receive assistance and technical guidance, veterinary and institutions such as SEBRAE.

This group is characterized as a network level and second Balestrin and Vargas [19]. The characteristics of this network, as shown in Table 1 of the literature, is shown in Table 2.

Table 2. Network Characteristics of Producers Association

\begin{tabular}{|l|l|l|}
\hline Features & Producers Association & Network types \\
\hline Types of stakeholders & $\begin{array}{l}\text { Milk Producers Association of Producers, private } \\
\text { enterprises, support institutions }\end{array}$ & Social Networks or LPA \\
\hline Way the actors & organizations and individuals & Social Networks \\
\hline Network functions & $\begin{array}{l}\text { mercantile exchanges, information, knowledge, } \\
\text { relationships, support and contacts }\end{array}$ & LPA or Cluster \\
\hline Type & In the market, support and communication & LPA \\
\hline network model & Horizontal & Social Networks \\
\hline $\begin{array}{l}\text { Organizations in a given } \\
\text { geographical area }\end{array}$ & Fartura / SP & Clusters, LPA or Social Networks \\
\hline Types of organizations & Public, private and third sector & clusters and social networks \\
\hline Level of Association & strategies of producers and dairy farms & Social Networks or LPA \\
\hline Actions & Cooperative and competitive & Clusters or LPA \\
\hline Interaction form & Formal and informal & clusters or Social Network \\
\hline $\begin{array}{l}\text { Essential factors in } \\
\text { establishing }\end{array}$ & trust, reputation and cooperation & Social Networks \\
\hline Establishment of goals & Association with the owners & Social Networks or LPA \\
\hline Types of objectives & Economic objectives, social, environmental and political & LPA \\
\hline Responsible for the actions & Association and the owners & Social Networks or LPA \\
\hline Supply chain & Unlinked & clusters \\
\hline Benefits & Economic, social and environmental & Social Networks or LPA \\
\hline Job type stimulated & Formal and informal & social networks or LPA \\
\hline
\end{tabular}

As for the theoretical framework of the Association of producers, there is the existence of mixed Social Networking features, prevalent, and the Local Productive Arrangement. 


\subsection{Business Models}

We use models of conventional and social business of Yunus et al. [10] to analyze the scenes before and after formation of the association of producers, Table 3 .

Table 3. Conventional and Social Business Models applied to association of producers. Source: Prepared by the author and adapted from Yunus et al. [10].

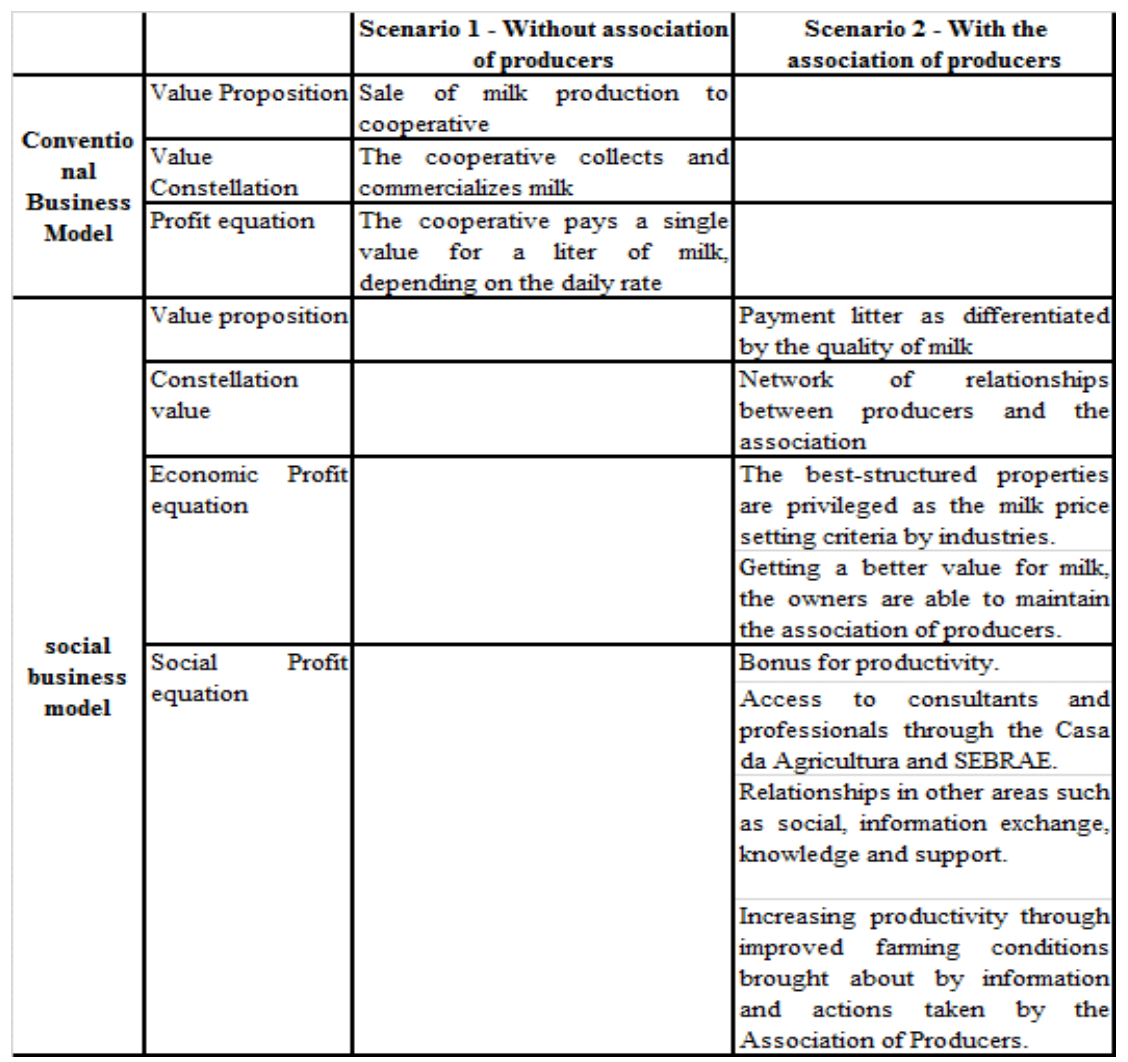

\section{Conclusion}

The fact that the producers have organized themselves into a network level showed that social benefits are greater than the economic benefit, but the main benefit is that contributes to the evolution of the producers themselves.

This case study can be interpreted as a social innovation, as the association of producers brought social and economic benefits for a community; there has been new products and processes in order to innovate the marketing and production of lasting and sustainable milk 


\section{References}

1. Dos Santos, A. B., Fazion, C. B., \& de Meroe, G. P.: Innovation: A Study on the Evolution of the Schumpeter Concept. Caderno de Administração. Revista da Faculdade de Administração da FEA (2011)

2. Juliani, D. P., Juliani, J. P., de Souza, J. A., Harger, E. M.: Social Innovation: Prospects and Challenges. Revista Espacios, 35(5) (2014)

3. Puffal, D. D. P., \& Puffal, C. W.: A Evolução do Campo de Estudos de Redes Interorganizacionais: Uma Análise de Publicações Internacionais das Relações entre Empresas. Brazilian Journal of Management \& Innovation), 1(3), 63-86 (2014)

4. Silveira, M. A. P.; Trefiglio, R. P.; Zambanini; M E; Ceo, M.: Sistemas Interorganizacionais e Redes de Empresas no Setor Automobilístico: Indicadores e Relações. Anais do $7^{\circ}$ CONTECSI, São Paulo (2009)

5. Dyer, J.H.; Singh, H.: The relational View: Cooperative Strategy and Sources of Interorganizational Competitive Advantage. Academy of Management Review, 23(4), 660-679, (1998)

6. Pereira, B. A. D.: Structuring of Horizontal Relationships in Networks. Thesis (Doctorate in Business Administration) - Universidade Federal do Rio Grande do Sul, Porto Alegre 219 f. (2005)

7. Balestrin, A.; Vargas, L. M.: Evidências Teóricas para a Compreensão das Redes Interorganizacionais. ENEO, Encontro de Estudos Organizacionais, São Paulo (2002)

8. Baum, J. A. C.; Ingram, P.: Interorganizational Learning and Network Organization: Toward a Behavioral Theory of the Interfilm. In: March, J.G. Augier, M. (eds) A Tribute to Richard M. Cyert. Aldershot UK: Edward Elgar (2000)

9. Cruz, J. A. W. et al.: Management of Sustainable Networks: A Case Study on a Network of Waste Pickers Associations, Editora Juruá, Curitiba (2009)

10. Yunus, M., Moingeon, B. and Lehmann-Ortega, L.: Building Social Business Models: Lessons from the Grameen Experience, Long Range Planning, 43(2-3) (2010)

11. Fleury, S.: Observatory on Social Innovation. In: Anais do Congresso Internacional del Clad Sobre la Reforma del Estado y de la Administración Pública, Buenos Aires (9) (2001)

12. Cloutier, J.: Crises. Qu'est-ce que l'innovation sociale? Crises (2003)

13. Bignetti, L. P.: Social Innovations: A Raid by Ideas, Trends and Research Focus. Ciências Sociais Unisinos, 47(1), 3-14 (2011)

14. Castor, B. V. J.: Social Innovation and Development. FIEP-Federação das Indústrias do Estado do Paraná (2007)

15. Murray, R., Caulier-Grice, J., Mulgan, G.: The Open Book of Social Innovation. London: National endowment for science, technology and the art (2010)

16. de Oliveira, N. D. A., da Silva, T. N.: Social Innovation and Sustainable Social Technologies Inter-cooperatives Relationships: An Exploratory Study. In: CREDITAG-RO. Revista de Administração da UFSM, 5(2), 277-295 (2012)

17. Gil, A. C. How To Design Research Projects. São Paulo, 5, 61 (2002)

18. Costa, M. A. F., Costa, M. F. B.: Research Methodology-Concepts and Techniques, Rio de Janeiro. InterCiência (2001)

19. Balestrin, A.; Vargas, L. M.: Evidências Teóricas para a Compreensão das Redes Interorganizacionais. ENEO, São Paulo (2002) 